\title{
Commercializing International Environmental Protection: A Review of the Kyoto Protocol to the United Nations Framework Convention on Climate Change and Its Market-Based Mechanisms
}

\author{
Empire Hechime Nyekwere \\ Lecturer, Department of Public Law, Faculty of Law, Redeemer's University, Osun State, Nigeria. Ph.D. \\ Research Candidate (Nnamdi Azikiwe University, Anambra State, Nigeria); LL.M. (University of Ibadan, Oyo \\ State, Nigeria); BL. (Lagos, Nigeria); LL.B. (Obafemi Awolowo University, Osun State, Nigeria)
}

\begin{abstract}
One of the most current pressing environmental problems threatening the well-being and survival of the global community is climate change. The change in the Earth's climate is believed to be caused by human-induced activities such as the several decades of uncontrolled emissions of greenhouse gases. There is now a universal consensus that climate change is a global problem that needs urgent global attention and response. The need to compel a paradigm shift in the emissions of several gases accountable for global warming with the resultant effect of climate change led to the negotiation of an international agreement known as the Kyoto Protocol. The Kyoto Protocol commits industrialized nations and nations with economies in transition to reduce their greenhouse gas emissions and achieve their reductions targets. To achieve its aim, the Kyoto Protocol initiated three innovative market-based mechanisms, now known as the carbon market, designed to help Parties meet their national greenhouse emissions reduction targets. This paper reviews the market-based mechanisms (Carbon Market) of the Kyoto Protocol to the United Nations Framework Convention on Climate Change to ascertain whether the Kyoto Protocol has achieved significant global greenhouse gas emissions reduction through its carbon market. The paper also examines the compliance mechanism, the successes, and failures of the Kyoto Protocol. The paper concludes with a recommendation that both the developed and developing countries must be involved in greenhouse gas emissions reduction if any significant global greenhouse gas emissions reduction is to be achieved.

Keywords: Kyoto Protocol, Kyoto Protocol market-based mechanisms, Kyoto compliance mechanism, Kyoto Protocol successes, Kyoto Protocol failures.
\end{abstract}

DOI: $10.7176 / \mathrm{IAGS} / 86-03$

Publication date:September $30^{\text {th }} 2020$

\section{INTRODUCTION}

Among the most severe environmental challenges that the world is facing is climate change. At the centre of climate change science are the increasing concentrations of carbon dioxide $(\mathrm{CO} 2)$ and other greenhouse gases in the Earth's atmosphere caused by the activities of man. Human activities have been shown to lead to increases in global atmospheric temperatures (global warming) and associated changes in the Earth's climatic system (climate change). ${ }^{1}$ According to Antonio Guterres-United Nations Secretary-General in his address to world leaders at the Climate Action Summit of the $74^{\text {th }}$ Session of the UN General Assembly on 23 September 2019, New York City, USA, "what once was called "climate change" is now truly a "climate crisis" and what was once called 'global warming' has more accurately become "global heating." 2 There is currently a broad scientific agreement that global climate change is rapidly becoming a certainty. The latest studies, such as the Stern Review of the British Government has demonstrated the enormous costs that could result should the global community fail to act. $^{3}$

The recent reports by the US Global Research Programme and the American Geo-physical Union shows the general scientific consensus of the reality of climate change, and the human role in its current pattern:

\footnotetext{
${ }^{1}$ Reporting the Business Implications of Climate Change in Sustainability Reports: A Survey Conducted by the Global Reporting Initiative and KPMG's Global Sustainability Services (KPMG Global Sustainability Services and the Global Reporting Initiative 2007) p. 7. <www.greenbiz.com/sites/default/files/document/CustomO16C4 5F89588.pdf $>$ accessed 8 May 2019.

${ }^{2}$ António Guterres' Address to the 74th Session of the UN General Assembly. $<$ https://un.dk/navigation/aboutthe-un $/ \% \mathrm{E} 2 \% 80 \% 8 \mathrm{~B} \% \mathrm{E} 2 \% 80 \% 8$ Bantonio-guterres-address-to-the-74th-session-of-the-un-general-assembly> accessed 27 September 2019; U.N. Head Warns Leaders the World Is Facing a 'Great Fracture'. <https://time.co munited-nations-climate-summit-economy> accessed 27 September 2019.

${ }^{3}$ The Kyoto Protocol and Global Climate Change: Towards a New Transatlantic Consensus? European Union Centre of the University of North Carolina EU Briefings, May 2007, p. 1. <http://europe.unc.edu/.../Brief_Kyot o_Protocol_Global_Climate_Change_New_Cons...> accessed 8 May 2017.
} 
Evidence for climate change abounds, from the top of the atmosphere to the depth of the oceans. Scientists and engineers from around the world have meticulously collected this evidence, using satellites and networks of weather balloons, observing and measuring changes in location and behaviours of species and functioning of ecosystems. Taken together, this evidence tells an unambiguous story: the planet is warming, and over the half-century, this warming has been driven primarily by human activity. Humanity is the major influence on the global climate change observed over the past 50 years. Rapid societal responses can significantly lessen negative outcomes. $^{1}$

After the early warnings and concerns about Global warming, the World Meteorological Organization and the United Nations Environment Programme created the Intergovernmental Panel on Climate Change (IPCC) in 1988. Its first report, published in 1990, and a series of other accounts highlighted the significance of global warming - the risks of climate change. And demonstrate with more scientific certainty than ever before that climate change is happening. And that it is due to the increase in anthropogenic greenhouse gas emissions ${ }^{2}$ released into the air from industries, homes, vehicles, and other energy-consuming activities. ${ }^{3}$ For instance, the IPCC noted that 11 of the last 12 years (1995 to 2006) are amongst the 12 warmest years on record when measuring global surface temperature since 1850 . All these scientific readings offer incontestable signals of global warming. ${ }^{4}$ Also, the IPCC has concluded that significant reductions in worldwide GHG emissions are needed to limit the increase in global temperatures to between $2^{\circ} \mathrm{C}$ and $4^{\circ} \mathrm{C} .^{5}$

The adoption and embracing of the United Nations Framework Convention on Climate Change (UNFCCC) in 1992, marks the beginning of the global political response to climate change. The UNFCCC sets out a framework for action designed to stabilize atmospheric concentrations of greenhouse gases to evade "dangerous anthropogenic interference" with the climate system. On 11 December 1997, delegates at the third Conference of Parties (COPs-3) to the UNFCCC in Kyoto, Japan consented to a Protocol to the UNFCCC that commits industrialized nations and nations in transition to a market economy (recognized as Annex I parties under the UNFCCC) to achieve emission reduction targets. These Annex I parties agreed to a reduction of their total emissions of six greenhouse gases by an average of 5.2\% below 1990 levels between 2008-2012 (the 1st commitment period), with precise targets varying from country to country. The Kyoto Protocol adopted 11 December 1997 entered into force on 16 February 2005 and now has more than 190 parties. $^{6}$

\footnotetext{
${ }^{1}$ Jonathan M. Harris and Brian Roach, Environmental and Natural Resource Economics: A Contemporary Approach, $4^{\text {th }}$ Edition, Chapter 12-The Economics of Global Climate Change. (Global Development and Environment Institute, Tufts University 2017); See American Geophysical Union (2014), Human-Induced Climate Change Requires Urgent Action. <www.agu.org> accessed 27 September 2029; Reidmiller, D.R., et. al., (eds.), Impacts, Risks, and Adaptation in the United States: Fourth National Climate Assessment, Volume II: Report-inBrief. (U.S. Global Change Research Program (USGCRP), Washington, DC, USA, 2018) pp. 1-186:24.

${ }^{2}$ See Moise Tsayem Demaze, 'The Obscure Future of the Kyoto Protocol' (2013) 41(4) Espace Geographique, 346-351. < halshs-00924455> accessed 10 May 2019.

${ }^{3}$ A Climate Change Plan for the Purposes of the Kyoto Protocol Implementation Act-2007. <www.ec.gc.ca/doc/ ed-es/p_123/cc_plan_2007_e.pdf> accessed 10 May 2019; See Climate Change 2007, The Physical Science Basis: Contribution of Working Group I to the Fourth Assessment Report of the International Panel on Climate $<$ https://www.ipcc.ch/site/assets/uploads/2018/03/ar4_wg2_full_report.pdf $>$ accessed 8 May 2019; See also Climate Change 2007, Impacts, Adaptation and Vulnerability, International Panel on Climate Change, Contribution of Working Group II to the Fourth Assessment Report of the International Panel on Climate Change. $<$ https://www.ipcc.ch/site/assets/ uploads/2018/03/ar4_wg2_full_report.pdf > accessed 8 May 2019.

${ }^{4}$ P. Mondal et. al., 'Critical Review of Trends in GHG Emissions from Global Automotive Sector' (2011) 1(1) British Journal of Environment \& Climate Change, 1-12:2; The Automotive Industry and Climate Change: Framework and Dynamics of the CO2 Revolution, p. 20. https://www.pwc.com/th/en/automotive/assets/co2.pdf accessed 10 May 2019.

${ }^{5}$ OECD/IEA 2011, Combining Bioenergy with CCS: Reporting and Accounting for Negative Emissions under UNFCCC and the Kyoto Protocol, International Energy Agency Working Paper, p. 8. <https://ideas.repec.org/p/ oec//2011-16-en.html> accessed 8 April 2019.

${ }^{6} \mathrm{~A}$ Brief History of the UNFCCC and the Kyoto Protocol. IISD. <www.ictsd.org/downloads/2010/05/iisd-briefon-the-unfccc-process.pdf $>$ accessed 15 April 2019; Johannes Bollen, Arjen Gielen, and Hans Timmer, Compliance with the Kyoto Protocol: Macroeconomics of Emissions Trading, Joint Implementation, and the Clean Development Mechanism, p. 2. <https://www.oecd.org/dev/1923199.pdf> accessed 9 April 2019; See Eliezer Martins Diniz, Lessons from the Kyoto Protocol, p. 32. <https://www.researchgate.net/.../232275671 Lessons_from_the_ky...> accessed 8 May 2019; See Robert Townsend, (2013) Revisiting the Kyoto Protocol: Reducing $\mathrm{CO}_{2}$ to Prevent Climate Change Disasters, Old Dominion University Model United Nations Society (ODUMUNC) 2014 Issue Brief for the World Conference, p. 2; See Douglas R., 'Williams et al, Rethinking the
} 
The Kyoto Protocol to the UNFCCC is an international agreement on climate change, in which industrialized countries and nations with economies in transition (together called "Annex I" Countries) agreed to reduce their greenhouse gas (GHG) emissions. ${ }^{1}$ The Kyoto Protocol seeks to mitigate dangerous anthropogenic changes to the Earth's climate by assigning to all Parties' common but differentiated responsibilities' that take into consideration each country's contributions to the greenhouse effect, and each nation's capability to remedy this contribution. ${ }^{2}$ The Kyoto Protocol aims to reduce emissions without jeopardizing economic growth. ${ }^{3}$ The Protocol also contains new qualitative and quantitative commitments for developed countries, including the establishment of a national scheme for estimating GHG emissions and removals, reporting of GHG emissions, and rules for the Protocol's three market-based mechanisms. ${ }^{4}$

The Kyoto Protocol, regarded as the first international relentless attempt to address GHG emissions and the prospect of climate change, ${ }^{5}$ shares the objective and institutions of the UNFCCC. The significant distinction between the two, however, is that while the UNFCCC encouraged industrialized countries to stabilize GHG emissions, the Kyoto Protocol commits them to do so. The comprehensive regulations for its implementation were adopted at COPs 7 in Marrakesh in 2001, and are called the Marrakesh Accords. ${ }^{6}$ The Kyoto Protocol supplements and strengthens the UNFCCC. Only Parties to the UNFCCC qualifies to become Parties to the Kyoto Protocol. The Kyoto Protocol is founded on the same principles as the UNFCCC and shares its ultimate objective, which is:

To achieve stabilization of atmospheric concentrations of greenhouse gases at levels that would prevent dangerous anthropogenic (human-induced) interference with the climate system $^{7}$

The Kyoto Protocol hence represents the world's realization that GHG emission levels are a global issue that must be tackled on an international scale. ${ }^{8}$ The Protocol contains legally binding commitments to either reduce or limit the emissions of six GHG. ${ }^{9}$ The six specific greenhouse gases covered by the Protocol are (1) carbon dioxide

Kyoto Protocol: Are There Legal Solutions to Global Warming and Climate Change?' (2006) 5 Wash. U. Global Stud. L. Rev., 333-380:336; See Shaheen Rafi Khan, The Kyoto Protocol and Sustainable Development. Working Paper Series No. 81, 2002. Sustainable Development Policy Institute; Summary of the UN Climate Change Conference - Poznan - $1 \ldots<$ http://enb.iisd.org/vol12/enb12395e.html > accessed 4 September 2019.

${ }^{1}$ McNamee, Daniel, 'Climate Change, the Kyoto Protocol, and the World Trade Organization: Challenges and Conflicts' (2006) 6(2) Sustainable Development Law \& Policy, 41-44:41, 65; Climate Change, the Kyoto Protocol, and the World Trade <... http://digitalcommons.wcl.american.edu/cgi/viewcontent.cgi?article= $1325 \&$ context $=$ sdlp $>$ accessed 4 September 2019.

${ }^{2}$ Matthew Coghlan, 'Prospects and Pitfalls of the Kyoto Protocol to the United Nations Framework Convention on Climate Change' (2002) 3 Melbourne Journal of International Law.

${ }^{3}$ Nicole G. I. Martínez-Zarzoso, Driving Factors of Carbon Dioxide Emissions and the Impact from Kyoto Protocol, CESIFO Working Paper No. 2758 Category 10: Energy and Climate Economics, August 2009, Presented at CESIFO Venice Summer Institute, July 2009.

${ }^{4}$ Xueman Wang and Glenn Wiser, 'The Implementation and Compliance Regimes under the Climate Change Convention and its Kyoto Protocol' (2002) 11(2) RECIEL, 186; See Kyoto Protocol Article 5(1), Article 7(1), Article 6, 12 and 17; See Hiraishi, T. (ed), IPCC 2014, 2013 Revised Supplementary Methods and Good Practice Guidance arising from the Kyoto Protocol' (IPCC, Switzerland), p. 4.

${ }^{5}$ J.W. Anderson. 1998. The Kyoto Protocol on Climate Change Background, Unresolved Issues and Next Steps (Resources for the Future, Washington DC.), p. 18.

${ }^{6}$ United Nations Framework Convention on Climate Change Fact Sheet: The Kyoto Protocol 2011, p. 2. $<$ https://unfccc.inf/files/press/backgrounders/application/.../press-factsh_mitigation.pdf $>$ accessed 9 March 2019 (Hereinafter, UNFCCC 2011).

${ }^{7}$ UNFCCC (2003) Caring for Climate: A Guide to the Climate Change Convention and the Kyoto Protocol, p. 21. $<$ https://unfccc.int/resource/docs/publications/caring_en.pdf $>$ accessed 9 March 2019; Kyoto Protocol wikizero.com. <https://www.wikizero.com/en/Climate_Change-Kyoto_Protocol> accessed 4 September 2019; The United Nations Framework Convention on Climate Change \& Kyoto Protocol: An introduction (Friends of the Earth, December 2008), p. 1. (Hereinafter UNFCCC \& Kyoto Protocol 2008); Global Warming| Globalization101. <http://www.globalization101.org/global-warming/> accessed 4 August 2019.

${ }^{8}$ Aiten Musaeva McPherson, 'Let Them Eat Carbon: The End of the Kyoto Protocol' (2012) 41 Ga. J. Int'l \& Comp. L., 219-250:222; <Let Them Eat Carbon: The End of the Kyoto Protocol < https://paperity.org/p/819985 31/let-them-eat-carbon-the-end-of-the-kyoto-protocol> accessed 5 August 2019.

${ }^{9}$ Alan Belward, Land Use Change and Forestry Implications of Global Change Public Policy, in Å. Rosenqvist et al, (ed), Remote Sensing and the Kyoto Protocol: A Review of Available and Future Technology for Monitoring Treaty Compliance, Ann Arbor, Michigan, USA, October 20-22, 1999, Workshop Report of the International Society for Photogrammetry and Remote Sensing - ISPRS Working Groups on Global Monitoring (VII/5) and Radar Applications (VII/6) in collaboration with the University of Michigan. 
(CO2); (2) methane (CH4); (3) nitrous oxide (N2O); (4) hydrofluorocarbons (HFCs); (5) perfluorocarbons (PFCs); and (6) sulphur hexafluoride (SF6). Of the six gases covered, Carbon dioxide, out of the six gases covered, is undoubtedly the most widespread in the atmosphere, with $76.7 \%$ of global greenhouse gas emissions credited to it. ${ }^{1}$

\section{KYOTO PROTOCOL MARKET-BASED MECHANISMS (CARBON MARKET)}

The requirement that countries reduce their greenhouse gas emissions is the central feature of the Kyoto Protocol. Emission reductions took on economic value when such targets were set. Negotiators of the Kyoto Protocol incorporated three market-based mechanisms explicitly: International Emissions Trading, Clean Development Mechanism, and Joint Implementation ${ }^{2}$, thereby creating what is now known as the "carbon market." ${ }^{3}$ The carbon market is intended to help countries meet their national emission targets and to encourage the private sector and developing nations to contribute to emission reduction endeavours. ${ }^{4}$ Thus, the Protocol broke new ground with these three innovative mechanisms created to enhance the cost-efficiency of climate change mitigation through opening means for Parties to cut emissions, or enhance carbon sinks more economically abroad than at home. Although the cost of limiting emissions or expanding removals varies significantly from state to state, the effect for the atmosphere is the same regardless of where the action is taken. ${ }^{5}$ These three market-based mechanisms shall, however, be discussed in detail.

\subsection{International Emissions Trading (IET)}

The International Emissions Trading Mechanism set out in Article 17 of the Kyoto Protocol permits nations that have agreed to greenhouse gas targets, or Annex I countries, to sell or buy additional emission units if they have units unused or need more units. This mechanism, however, does not apply to non-Annex I countries. ${ }^{6}$ The Emissions Trading Mechanism, which created a new commodity, allows developed countries to purchase carbon credits from other nations with unused capacity to help meet their commitments. ${ }^{7}$ In other words, Annex I Parties are permitted, for instance, to purchase Assigned Amount Units (AAUs) based on International Emissions Trading (IET) under Article $17 .^{8}$

An emission trading system is an innovative approach to the problem of climate change. A helpful broad explanation of the mechanics behind this new environmental policy instrument (NEPI) states as follows: Tradable permit represents a right granted by a government to the permit holder to emit a specified quantity of gases. By issuing only a limited number of permits, governments can control the total quantity of gas emitted, on a local, national, or international level. Because permits are usually limited to a quantity that is less than the amount of gas that would normally be emitted, the right to emit becomes a valuable commodity. If the trading of permits is allowed, then a market price will be established. Those wishing to emit the specified gases beyond permitted levels must either reduce their emissions or purchase permits to emit. Polluters able to reduce their emissions relatively cheaply will do so, rather than purchase permits. Those polluters who face higher abatement costs will tend to buy permits to satisfy government requirements. In this way, reductions in emissions are made by those polluters

\footnotetext{
${ }^{1}$ McPherson, p. 225; See Vicky Pope, The role of science in the Kyoto protocol, pp. 113-126:113. < https:// www.ecmwf.int/sites/default/files/.../11710-role-science-kyoto-protocol.pdf $>$ accessed 9 March 2019; See Belward ibid; Papalia Angela, (2005) 'Australia: Greenhouse emissions and the Kyoto Protocol' (2005) 11(1) The National Legal Eagle, 16-20.

${ }^{2}$ UNFCCC (2007), The Kyoto Protocol Mechanisms: International Emissions Trading, Clean Development Mechanism and Joint Implementation, United Nations Framework Convention on Climate Change. $<$ https://unfccc:int $>$ doc $>$ publications $>$ mechanisms $>$ accessed 8 March 2019; UNFCCC \& Kyoto Protocol 2008, supra note 15 .

${ }^{3}$ New Perspectives on the Kyoto Protocol; See Ana-Maria Boromisa and Sanja Tisma, 'The Kyoto Protocol: Can We Meet?’ (1331-1182) XIII (2007), 46/47 Croatian International Relations Review, 29-37:32.

${ }^{4} \mathrm{UNFCCC}$ (2007), supra note 20.

${ }^{5}$ UNFCCC (2003), supra note 16, p. 19; The Kyoto Protocol - Pan American Health Organization. $<$ http://www.bvsde.paho.org/bvsacd/cd68/caring/kyoto.pdf > accessed 5 August 2019; Malta: Climate change: investment opportunities/IFLR.com. <http://www.iflr.com/Article/2323047/Malta-Climate-change-investmentopportunities.html $>$ accessed 4 September 2019.

${ }^{6} \mathrm{McPherson}$, supra note 17 , p. 228.

${ }^{7}$ Edward Page, 'Equity and the Kyoto Protocol: Analysis' (2007) 27(1) Politics, 8-15:10

${ }^{8}$ Woerdman E., (2005). 'Hot Air Trading under the Kyoto Protocol: An Environmental Problem or Not?' (2005) 14(3) European Environmental Law Review, 71-77; See Oberthür, S. and H.E. Ott, The Kyoto Protocol: International Climate Policy for the 21st Century (Berlin: Springer 1999) p. 275.
} 
who can do so at least cost, being compensated by polluters who face higher costs of abatement. ${ }^{1}$

By the provisions of Article 17 of the Protocol, the industrialized country Parties may achieve their commitments using emissions trading. The Emissions Trading Mechanism operates by setting a legally binding limit on every Party's emissions (the assigned amount) and then allowing Parties to trade part of this. After the completion of all trading, the total sum of emissions (assigned amounts) should equal the total sum before any trading began. Thus, trading redistributes the allowed emissions from one Party to another but keeps the total emissions within the initially agreed limit. The preceding procedure implies that industrialized nations whose emissions are below their assigned amounts can sell the unused portion to nations whose emissions exceed their assigned amounts. The net effect is equally as if both countries attained their commitments given that emissions are subtracted from the assigned amount of the selling country and added to the assigned amount of the buying country. ${ }^{2}$

Article 17 of the Protocol allows Annex I countries to trade their assigned amount units (AAUs) by transferring Kyoto units to or acquiring units from a different Annex I Party. Thus, IET does not change the total cap of Annex I countries, but only redistributes the AAUs between them. ${ }^{3}$ That is, under this trading mechanism, countries with commitments under the Kyoto Protocol can obtain emission units from other countries that have commitments under the Protocol and employ them to meet up a part of their Kyoto targets. ${ }^{4}$ It enables Parties to pursue cheaper opportunities to curb emissions or increase removals wherever those opportunities exist, to minimize the general cost of mitigating climate change. Annex I Parties may also acquire, from other Annex I Parties, CERs from CDM projects, ERUs from joint implementation projects, or RMUs from sink activities.

Nevertheless, the number of units that a Party may transfer to other Parties is restricted by the Party's commitment period reserve (CPR). The CPR is the lowest level of units that a Party has to hold in its national registry at every time. The obligation for every Party to keep a CPR stops a Party from over-transferring units. ${ }^{5}$ The Kyoto Protocol encouraged the formation of the European Union emissions trading scheme, and several people anticipate the expansion and connecting of emission markets globally. ${ }^{6}$

Thus, this International Emission Trading Mechanism (IETM), allows any Annex I Party that has reduced GHG emissions below its assigned national quantified emission limitation and reduction commitments (QELRCs) to sell any such additional emission reduction units ('ERUs') to a different Annex I Party, which may, in turn, use these ERUs to their own national QELRCs instead of actual domestic reductions. ${ }^{7}$ In other words, Annex I countries can trade Assigned Amount Units (AAUs) among themselves. AAUs are allotted to Annex I parties at the commencement of every commitment period based on each Party's targets outlined out in Annex B of the Protocol. By the end of a commitment period, an Annex I country must comply with its responsibilities under the Kyoto Protocol in a manner that its emissions of GHGs are either below or equal to its AAUs. ${ }^{8}$ This emissions trading scheme would parallel the ultimate market in certified emission reductions (CERs) expected by the Kyoto Protocol, given that both are market-based mechanisms intended at providing Annex I Parties with the flexibility to meet their QELRCs in the most cost-effective location and manner possible. ${ }^{9}$

\footnotetext{
${ }^{1}$ Chad Damro and Pilar Luaces-Méndez, The Kyoto Protocol's Emissions Trading System: An EU-US Environmental Flip-Flop. P. 2. <...http://aei.pitt.edu/874/1/Kyoto.pdf> accessed 9 March 2019; See Dobes Leo, (1999), 'Kyoto: Tradable Greenhouse Emission Permits in the Transport Sector' (1999) 19(1) Transport Review, 81-97:81-82; Damro, Chad and Luaces-Méndez, Pilar, 'The Kyoto Protocol's emissions trading system: An EUUS Environmental Flip-Flop' Working Paper No.5, August 2003.

${ }^{2}$ Greenpeace 1998, Guide to the Kyoto Protocol, October 1998. <www.apmath.spbu.ru/ru/structure/depts/mmes /kyoto/1.pdf $>$ accessed 12 March 2019; Hamed Hashemi, The Kyoto Protocol and the Barriers towards its Proper Implementation (The Juris, April 10 2014).

${ }^{3}$ Romain Morel and Igor Shishlov, Climate Report No. 44 - Ex-Post Evaluation of the Kyoto Protocol: Four Key Lessons for the 2015 Paris Agreement. Research on the Economics of Climate Change, May 2014, p. 4. $<$ http://www.cdcclimat.com/IMG/pdf/14-05_climate_report_no44_-_analysis_of_the_kp-2.pdf $>$ accessed 12 May 2019.

${ }^{4}$ UNFCCC (2007), supra note 20, p. 5.

${ }^{5}$ UNFCCC (2008), Kyoto Protocol Reference Manual on Accounting of Emissions and Assigned Amount. United Nations Framework Convention on Climate Change, p. 16 (Hereinafter UNFCCC 2008); UNFCCC (2003), supra note 16 , p. 20.

${ }^{6}$ UNFCCC (2007), supra note 20, p. 5.

${ }^{7}$ Coghlan, supra note 11 .

${ }^{8}$ Christopher Carr and Flavia Rosembuj, 'Flexible Mechanisms for Climate Change Compliance: Emission offset purchases under the Clean Development Mechanism' (2008) 16 N.Y.U. Environmental Law Journal, 44-62: 4648.

${ }^{9}$ Coghlan, supra note 11 .
} 


\subsection{Clean Development Mechanism (CDM)}

Article 12 of the Kyoto Protocol allows Annex I countries to offset their emissions by investing in emissions reduction projects in non-Annex I (developing) nations without emission caps. Emission reduction achieved through these projects has to be additional to any that would happen in the absence of the certified project activity. The CDM projects, therefore, generate Certified Emission Reductions (CER)-carbon credits that can be applied by Annex I countries for compliance with their Kyoto targets in addition to their AAUs. In other words, under this mechanism, Annex I Parties might meet up part of their QELRCs by investing in sustainable development contributing projects in non-Annex I Parties. These projects must be approved by the Conference of the Parties serving as the Meeting of the Parties $(\mathrm{COP} / \mathrm{MOP})^{1}$ and must have real, measurable, and long-term benefits related to the mitigation of climate change'.2

The CDM allows emission-reduction (or emission-removal) projects in developing nations to receive certified emission reductions (CERs), each one equivalent to one tonne of CO2. These CERs can be traded and sold, and used by developed nations under the Kyoto Protocol to meet up a part of their emission reduction targets. In other words, the CDM permits Annex I countries to fund projects that decrease emissions in developing countries that are Kyoto parties but without commitments to reduce their GHG emissions. In return, Annex I countries receive CERs from those projects. These CERs can then be utilized for compliance in Annex I countries. Thus, under the $\mathrm{CDM}$, emission credits generated from climate-friendly projects in the developing countries can be used for compliance intentions in the developed world. Therefore, CDM permits developed countries with binding targets to implement emission-reducing projects in developing countries and use the CERs ensuing from such project activities to add to compliance with part of their quantified emission restriction and reduction commitments. ${ }^{3}$

The CDM Executive Board oversees the mechanism and is responsible for registering projects, granting methodologies for deciding project baselines and monitoring emission reductions, issuing CERs, and for the accreditation of designated operational entities (DOEs). ${ }^{4}$ The CDM Executive Board is ultimately answerable to the countries that have ratified the Kyoto Protocol. The CDM is the first international environmental investment and credit scheme of its type, providing a standardized instrument for offsetting emissions, namely CERs. ${ }^{5}$ The system fuels sustainable development and emission reductions while giving industrialized countries some flexibility in the manner of meeting their emission reduction or limitation targets. The projects must qualify through a rigorous and public registration and issuance procedure intended to guarantee actual, computable, and provable emission reductions that are supplementary to what would have happened without the projects. ${ }^{6}$

This mechanism, like the other mechanisms, is utilized to help Annex I countries meet their targets. However, a critical difference between the CDM and the other two market-based mechanisms is that the CDM's purpose is to allow both Annexes I and non-Annex I countries to participate. The CDM achieves this objective by supporting non-Annex I parties to attain sustainable development at the same time as also assisting Annex I countries comply with their emission targets. The CDM's inclusion of all countries allows developing countries to profit from new funding opportunities, and industrialized nations to meet their reduction targets at a lower cost. ${ }^{7}$ Hence, the Kyoto Protocol established the CDM with the double purpose of assisting Non Annex I (NAI) countries in attaining sustainable development and in contributing to the ultimate objective of the UNFCCC; and assisting Annex I (AI) Parties in meeting their mitigation targets inscribed in Annex B of the Kyoto Protocol at an economical rate. ${ }^{8}$

The CDM is primarily a joint implementation between a donor country (a developed country) with a commitment and a host country (a developing country) without a commitment. Developed countries pay for projects undertaken in developing countries. Under Article 12, the projects must generate CERs which the donor country can use to achieve its emission commitment. ${ }^{9}$ The $\mathrm{CDM}$ can attract capital for projects that are Kyoto

${ }^{1}$ Coghlan, supra note 11; Kyoto Protocol, Arts 12(3)(B) \& 12(4); Morel and Shishlov, supra note 29.

${ }^{2}$ Kyoto Protocol, Art 12(5)(B).

${ }^{3}$ UNFCCC (2008), supra note 30, p. 16; Carr and Rosembuj, supra note 31; McPherson, supra note 17, p. 228; See Page, supra note 25.

${ }^{4}$ Ibid.

${ }^{5}$ UNFCCC (2007), supra note 20, pp. 5-6; Susan R. Fletcher, Global Climate Change: The Kyoto Protocol. Congressional Research Service Report for Congress. July 21, 2005, p. 5. <https://nationalaglawcentre.org/wpcontent/uploads/assets/crs/RL30692.pdf > accessed 15 February 2019.

${ }^{6}$ UNFCCC (2008), supra note 31, p. 16.

${ }^{7}$ McPherson, supra note 24, p. 229.

${ }^{8}$ Lambert S. D. B, Martin C. S. H, and Jürg F., Market Mechanisms in the Paris Agreement-Differences and Commonalities with Kyoto Mechanisms. Discussion Paper. German Emissions Trading Authority (DEHSt) at the German Environment Agency. October 2016, p. 6. <https://mediamanager.sei.org/documents/Publications/ Climate/DEHSt-2016-Market-mechanisms-Paris-Agreement-Kyoto-Protocol.pdf> accessed 6 March 2019.

${ }^{9}$ Greenpeace, supra note 28 . 
Protocol compliant, expected to create investment in developing countries, encourage active participation of private and public sectors, particularly from the private sector, improve and provide tools for technology transfer of new environmentally sustainable industries, define investment priorities on projects that meet sustainable development goals and advance sustainable development in general. ${ }^{1}$ Under the CDM mechanism, Annex I Parties are permitted to execute sustainable development project activities that lessen emissions in non-Annex I Parties. Also, the CDM helps non-Annex I Parties work towards sustainable development, and so contribute to the ultimate objective of the UNFCCC. Annex I Parties can apply the CERs produced by such projects to help meet their own emissions targets. ${ }^{2}$

The CDM is also a project-based mechanism. For example, CDM credits may be generated from emission reduction projects or afforestation and reforestation projects in non-Annex I Parties. CDM projects generate three kinds of Kyoto units. Certified emission reductions (CERs) are given for projects that reduce emissions, while temporary Certified Emission Reductions (tCERs) and long-term Certified Emissions Reductions (1CERs) might be issued for projects that enhance removals through afforestation and reforestation projects. ${ }^{3}$ The CDM is the sole mechanism that allows developing countries to be part of the carbon market by allowing industrialized countries to gain Certified Emission Reduction credits (CERs) by investing in projects that reduce GHG emissions in developing countries. Accordingly, the CDM was designed to allow both developed and developing countries involved profit from the mechanism. ${ }^{4}$

\subsection{Joint Implementation (JI)}

Article 6 of the Kyoto Protocol allows the industrialized countries in Annex 1 to meet their commitments through the use of joint implementation (JI). Unlike international emission trading (IET), JI is a project-based system with a requirement that projects be additional to what would otherwise have occurred. Like IET, economically, it has the effects of evening out the costs of reducing emissions. ${ }^{5} \mathrm{JI}$ allows industrialized countries to work together to achieve Kyoto targets. Thus, a country with a binding emissions target can meet a part of that target by investing in a project aimed at reducing emissions in any sector of another Annex I country's economy. ${ }^{6}$

The JI provisions allow Annex I parties to transfer to or acquire emission reduction units (ERUs) from other Annex I parties generated by projects that reduce human-made GHGs or enhance the anthropogenic removal of such gases by sinks. ${ }^{7}$ This mechanism provides emissions credits for developed countries that implement cooperative emissions reductions projects or remove carbon from the atmosphere through other mechanisms. ${ }^{8}$ Thus, under this mechanism, Annex I countries can invest in greenhouse gas-reducing projects in separate Annex I countries to earn emission reduction units that are counted towards their binding emission targets. ${ }^{9}$

Under the JI mechanism, one country can receive emission reduction credits when it funds an emissionreduction project in another country. ${ }^{10}$ Article 6 of the Kyoto Protocol allows Annex 1 countries to offset their emissions by investing in emission reductions projects in other Annex 1 countries. JI projects, therefore, produce Emission Reduction Units (ERU), which have to be converted from the assigned amount units (AAUs) of the host country. Thus, JI does not affect the total cap or assigned amount of Annex 1 countries or Parties collectively, but only redistributes the emissions reduction efforts or assigned amount among them. ${ }^{11}$

Through JI, a country which has an emission reduction commitment under the Kyoto Protocol might participate in an emission reduction (or emission removal) project in any other country with a commitment under the Protocol, and calculate the resulting emission units towards meeting its Kyoto target. ${ }^{12}$ In other words, JI is a

\footnotetext{
${ }^{1}$ Theodore Okonkwo, 'Carbon Credit Development: Is Nigeria Ready for International Trading?' (2015) 4(13) International Journal of Innovative Research \& Development, 320-331:322.

${ }^{2}$ UNFCCC (2003), supra note 16, p. 21; Paul Bourne, Bamboo and sustainable development in Viet Nam, $<$ https://www.bamboo.org.au/wp-content/uploads/2017/03/Bamboo-and-sustainable-development.pdf $>$ accessed 4 September 2019.

${ }^{3}$ UNFCCC (2008), supra note 31, p. 16.

${ }^{4}$ Damilola S. Olawuyi, 'From Kyoto to Copenhagen: Rethinking the Place of Flexible Mechanisms in the Kyoto Protocol's post 2012 Commitment Period' (2010) 6(1) Law, Environment and Development Journal, 21-35:24.

${ }^{5}$ Greenpeace, supra note 28.

${ }^{6}$ See Kamala Muhovic-Dorsner, Kyoto Protocol Flexibility Mechanisms: Promise or Perdition for Environmental Sustainability and Equity? Paper presented at the conference "Questioning Market Panacea in Environmental Policy and Conservation" organized by the Institute for Social Studies, The Hague, Netherlands.

${ }^{7}$ Carr and Rosembuj, supra note 33.

${ }^{8}$ Page, supra note 25; See Grubb, M., C. Vrolij and D. Brack, The Kyoto Protocol (London: Earthscan 1999).

${ }^{9}$ McPherson, supra note 17 , p. 229.

${ }^{10}$ Fletcher, supra note 38, p. 4.

${ }^{11}$ Morel and Shishlo, supra note 29.

${ }^{12}$ UNFCCC (2007), supra note 20, p. 7; Article 6 of the Kyoto Protocol.
} 
project-based mechanism that allows one Annex I Party to invest in a project that cuts emissions or enhances sequestration in a separate Annex I Party, and obtain credit for the emission reductions or removals realized in the course of that project. ${ }^{1}$

As has been noted earlier, JI projects earn ERUs by implementing projects that reduce emissions or increase removals using sinks, in other Annex I countries. Annex 1 parties can use ERUs generated by JI projects to meet their emissions targets. Each of the ERUs earned through JI projects is equivalent to one tonne of CO2. An equal subtraction is made from the host Party's assigned amount in other to avoid double accounting. ${ }^{2}$ Accounting is one of the essential elements in the carbon market. ${ }^{3}$ Proper accounting provisions and governance are critical to ensuring environmental integrity, which is one of the cornerstones of this market framework. In this context, avoiding double counting and ensuring that the tracking of transfers is done correctly, which reassures all market participants of the safety of their investments, are just two examples. ${ }^{4}$ The mechanisms operate based on accounting units, to be tracked and recorded through national registries that the Annex I Parties establishes and maintains.

The international transaction log (ITL), which became operational in November 2007, is a software-based (sophisticated computerized) accounting system that ensures the secure transfer of emission reduction units (ERUs) between countries. ${ }^{5}$ The ITL, which is administered by the UNFCCC secretariat, confirms the legality of transactions of Kyoto units by national registries and the CDM registry. The ITL tests each transaction to ensure that it conforms to the general rules for accounting of assigned amount, as well as specific standards for the particular mechanism and transaction in question. Only the transaction that has passed all these checks will be approved. ${ }^{6}$

JI projects result in emission reduction units (ERUs), and CDM projects generate certified emission reductions (CERs). Under international emissions trading, Parties may exchange assigned amount units (AAUs), CERs and ERUs, as well as removal units (RMUs) generated through sink activities in the land-use, land-use change, and forestry (LULUCF) sector. Each of these units equates to one tonne of carbon dioxide equivalent (calculated using the Global Warming Potential index), and each unit will have a unique, traceable serial number. The compilation and accounting database will record the emissions of Parties as reported in annual inventories, together with their total annual transactions of AAUs, CERs, ERUs, and RMUs. The ITL maintained by the secretariat will be an extra monitoring tool. ${ }^{7}$ In other words, the Kyoto units, that is, the AAUs, CERs, ERUs, and RMUs transactions are administered by the UNFCCC through the International Transaction Log (ITL). ${ }^{8}$

Just like the CDM, all emission reductions must be real, measurable, verifiable, and additional to what would have occurred without the JI projects. ${ }^{9} \mathrm{JI}$ has two 'tracks' of project application approval: Track 1 , in which the Hosting Party makes verification, and Track 2, in which verification is the duty of the Joint Implementation Supervisory Committee, accountable finally to the countries that have ratified the Kyoto Protocol. ${ }^{10}$

\section{KYOTO PROTOCOL COMPLIANCE MECHANISM}

The Kyoto Protocol's ultimate effectiveness depends on whether parties comply with their obligations. The Protocol's mechanism to ensure compliance consists of an independent Compliance Committee made up of a facilitative branch and an enforcement branch whose objective is to facilitate, promote and enforce compliance with the commitments under the Protocol. The compliance mechanism also includes mechanisms to generate performance information, to facilitate compliance, and to deter non-compliance through penalties. ${ }^{11}$ Thus, the Compliance Committee was established to facilitate, promote, and enforce compliance with the commitments under the Kyoto Protocol. ${ }^{12}$ The two branches of the Compliance Committee principally base their determinations

${ }^{1}$ UNFCCC (2008), supra note 31, p. 17; Vikas Kumar, Presentation on Emission Trading <http://www.authors tream.com/Presentation/vikaslkk2-2272452-presentation-emission-trading/> accessed 4 September 2019.

${ }^{2}$ UNFCCC (2003), supra note 15, p. 20.

${ }^{3}$ See Articles 4.2-4.13 of the Kyoto Protocol.

${ }^{4}$ Andrei M, Governance of Article 6 of the Paris Agreement and Lessons Learned from the Kyoto Protocol. Fix ing Climate Governance Series, Paper No. 4-May 2017 (Centre for International Governance Innovation) p. 7.

${ }^{5}$ See UNFCCC (2007), supra note 20, p. 5; See Article 6 of the Kyoto Protocol.

${ }^{6}$ See UNFCCC (2008), supra note 31, p. 22.

${ }^{7}$ UNFCCC (2003), supra note 16, p. 24.

${ }^{8}$ Morel and Shishlov, supra note 29.

${ }^{9}$ UNFCCC (2007), supra note 20, p. 7; Article 6 of the Kyoto Protocol.

${ }^{10}$ UNFCCC (2007), ibid; See Article 6, ibid.

${ }^{11}$ See Trade and Climate Change: A Report by the United Nations Environment Programme and the World Trade Organization (World Trade Organization, 2009), p. 75. (Hereinafter, Trade and Climate Change).

${ }^{12}$ UNFCCC (2008), supra note 31, p. 28. 
of compliance on reports from experts, subsidiary bodies, member Parties, non-governmental, and intergovernmental organizations. ${ }^{1}$

Each branch of the Compliance Committee has its separate functions. As its name indicates, the facilitative branch is intended to facilitate and promote compliance by the parties with the Protocol commitments. Thus, it is responsible for providing advice, assistance, and facilitation to the Parties in implementing the Protocol and for promoting compliance by the Parties with their Protocol commitments. It is also responsible for providing early warning of potential non-compliance. Furthermore, the facilitative branch determines whether an Annex I Party is in compliance with the following responsibilities: First, its qualified emissions limitation or reduction commitment under Article 3.1 of the Protocol; Second, the methodological and reporting requirements under Articles 4, 5.1-2 and 7.1 of the Protocol; and Third, the eligibility requirements under Articles 6, 12 and 17 of the Protocol (Section V.4 a-c of the procedure). ${ }^{2}$

In carrying out its tasks, the facilitative branch (which is required to take into account the principle of common but differentiated responsibilities) may do one or more of the following things. Firstly, provide advice and facilitate the provision of assistance to individual Parties regarding the implementation of the Protocol; Secondly, facilitate financial and technical support, including technology transfer and capacity building, taking into account Article 4.3-5 of the UNFCCC; and thirdly, assist in the formulation of recommendations to the Party in question, taking into account Article 4.7 of the UNFCCC. ${ }^{3}$ However, the authority given to the facilitative branch permits it not only to advice countries on how to achieve their targets and reduce emissions but also gives it the ability to help flag potential non-compliance. ${ }^{4}$

The enforcement branch has the responsibility to decide the consequences for Parties not meeting their Kyoto commitments. The enforcement branch not only observes a Party's non-compliance but also establishes a course of action to be taken to remedy the non-compliance. ${ }^{5}$ Thus, the role of the enforcement branch is more judicial. It considers whether a party has:

i) Complied with its methodological and reporting requirements where it's an accounting of emissions, and the assigned amount is concerned, under the Protocol.

ii) Met the eligibility requirements for participating in the flexible mechanisms of the Kyoto Protocol (international emissions trading, Clean Development Mechanism, and Joint Implementation), and

iii) Attained its emissions target (i.e., commitment) under the Kyoto Protocol. ${ }^{6}$

As well as determining non-compliance by a Party, the enforcement branch is also responsible for establishing and applying consequences for non-compliance with Article 3, paragraph 1, commitment. The enforcement branch even has the authority to suspend and reinstate a Party's eligibility to participate in the Kyoto mechanisms.

The enforcement branch has three essential roles concerning the accounting of emissions and assigned amount:

(a) It can make adjustments to a Party's inventory and corrections to its holdings of Kyoto units if the Party does not agree with the adjustment or correction applied by the expert review team (ERT) under Article 8 . The adjusted inventory estimations or corrected assigned amount holdings will be recorded in the compilation and accounting database (CAD) and become the official data for compliance reasons; ${ }^{7}$

(b) It can suspend and reinstate a Party's eligibility to take part in the Kyoto mechanisms. The branch will suspend eligibility at any time it establishes that a Party is in non-compliance with a commitment connected to eligibility. It can reinstate the Party's eligibility as soon as the Party has proved that it is no longer in noncompliance with the specific commitment that resulted in the loss of its eligibility; ${ }^{8}$

${ }^{1}$ McPherson, supra note 17, p. 230.

${ }^{2}$ Malgosia Fitzmaurice, 'The Kyoto Protocol Compliance Regime and Treaty Law' (2004) 8 Singapore Year Book of International Law (SYBIL), 23-40:29.

${ }^{3}$ Ibid; See Section XIV of the procedure; UNFCCC (2008), supra note 28, p. 28; See Chapter 5, The Kyoto Protocol-DocShare.tips. <http://docshare.tips/chapter-5-the-kyoto-protocol_5762cd80b6d87f35b18b493b. html> accessed 5 September 2019.

${ }^{4}$ McPherson, supra note 16, p. 230; Fitzmaurice, supra note 70, p. 29.

${ }^{5}$ McPherson, ibid, p. 230; Fitzmaurice, ibid, p. 29.

${ }^{6}$ Diarmuid Torney and Noriko Fujiwara, National Commitments, Compliance and the Future of the Kyoto Protocol (Centre for European Policy Studies (CEPS) No. 226/November 2010) pp. 4-5.

${ }^{7}$ UNFCCC (2008), supra note 30, section v, para 5, p. 29; See UNFCCC 2017, Kyoto Protocol Reference Manual on Accounting of Emissions and Assigned Amounts for the second commitment period of the Kyoto Protocol 2013-2020, Draft for discussion, Version 01.00. <http://unfccc.int/files/national_reports/annex_i_ghg _inventories/review_process/application/msword/kp-manual_20170213_stream2_clean-for-web.doc $>$ accessed 5 September 2019;

${ }^{8}$ UNFCCC (2008), ibid, section xv, para 4. 
(c) It has the authority to establish non-compliance with a Party's emissions commitment at the end of the commitment period. If the branch proves that the Party's emissions have exceeded its available assigned amount, it will apply the following consequences:

i. Deduct tonnes from the assigned amount of the next commitment period, equal to 1.3 times the amount of excess emissions;

ii. Oblige the Party to develop a compliance action plan;

iii. Suspend the Party's eligibility to transfer units. ${ }^{1}$

\subsection{Eligibility Criteria for Kyoto Protocol Mechanism}

The Kyoto Protocol entails that a Party must meet six specific criteria to be eligible to participate in the Kyoto mechanisms. These criteria are dependent on the methodological and reporting prerequisites in Article 5, paragraphs $1 \& 2$, and Article 7, paragraphs $1 \& 4$. These eligibility criteria aid in making sure that a Party is accounting correctly for its emissions and assigned amount, with the intention that the use of the Kyoto mechanisms will not endanger a Party in complying with its Article 3, paragraph 1 commitment. A Party's eligibility to take part in the Kyoto mechanisms will be decided as a reasonable result of the review and compliance procedures following submission of the initial report, and after that, through the annual review and compliance procedures. $^{2}$

There are six precise criteria for eligibility to participate in the Kyoto mechanisms. They are:

(a) The Party is a party to the Kyoto Protocol;

(b) The Party's initial assigned amount has been ascertained and recorded in the CAD;

(c) The Party's national system complies with the requirements established under Article 5, paragraph 1;

(d) The national registry of the Party complies with the requirements established under Article 7, paragraph 4;

(e) The inventory of the Party for the most current year has been submitted, and this inventory complies with Article 7, paragraph 1 requirements; and

(f) The Party has submitted and filed information on its assigned amount provided for in Article 7, paragraph 1, and has accurately accounted for additions to and subtractions from its assigned amount. ${ }^{3}$

Identical eligibility criteria apply to all three Kyoto Protocol mechanisms. Also, the use of the requirements of Article 6, paragraph 4, for JI is connected to the same criteria (a-f). Inability to meet criteria (a), (b) or (d) above will put a stop to participation in any of the Kyoto Protocol mechanisms. On the other hand, the result of not meeting the eligibility criteria linked to (c), (e) and (f) is different for each mechanism:

(a) For emissions trading, failure to comply with whichever of these criteria will stop a Party from transferring or acquiring units;

(b) For JI, failure to meet whichever of these criteria will stop a host Party from using JI Track 1, although the Party might use JI Track 2 (i.e., verification of project-related emission reductions must happen through JISC procedures). Nevertheless, a Party must have a national registry in place to issue and transfer ERUs under JI Track 2;

(c) For the CDM, failure to meet whichever of these criteria will stop a Party from retiring CERs to be applied for compliance with the requirements under Article 3, paragraph 1. It ought to be noted, still, that the Party will always be able to acquire CERs from the CDM registry. ${ }^{4}$

\section{SUCCESSES OF THE KYOTO PROTOCOL}

4.1 The Kyoto Protocol Birthed a Renewed Global Awareness of the Need to Reduce Greenhouse Gas Emissions and Protect Our Global Environment

The main achievement of the Kyoto Protocol is creating consciousness to the reality that we have to reduce global greenhouse gas emissions and protect the global environment. Even though the goals of the Protocol are not met, it will have been a high preliminary point. The Protocol is helping the world work collectively to save from harm our planet, much like the world united together to remedy the Ozone Hole calamity. It shows that many countries are serious about environmental protection and show others the need to be less selfish and focus on what's important: the protection of Earth. ${ }^{5}$ Several nations have followed through on their agreement and cut greenhouse gas emissions; an example is the European Union.

The Kyoto Protocol is the outcome of an agreement between the nations of the world that climate change resulting from human activities is a specific danger and that tangible action must be taken. The treaty goes further

\footnotetext{
${ }^{1}$ Ibid; section xv, para 5 .

${ }^{2}$ Ibid, section v, para 4.

${ }^{3}$ Ibid, p. 40.

${ }^{4}$ UNFCCC (2017), supra note 74, p. 72.

${ }^{5}$ Michael Chavez, The Kyoto Protocol Accomplishments and Failures, p. 9. < docplayer.net/20889972-The-kyotoprotocol-accomplishments-and-failures-by-micha...> accessed 12 February 2019.
} 
than the intentional emissions controls of previous international agreements. It is legally binding, with defined compliance measures. The treaty is an acknowledgment by the world's foremost industrial nations that the scientific evidence for climate change is currently too strong that it can no longer be overlooked. The preceding is a position that has been adopted by a growing number of multinational corporations. According to John Browne, Group Chief Executive Officer (CEO) of British Petroleum in a speech on the treaty's implications:

We've moved, as the psychologists would say, beyond denial. There's a growing consensus that climate change is an issue we have to take seriously. ${ }^{1}$

4.2 The Kyoto Protocol Has Inspired Climate Policy and Represents a Significant Step Forward in the Multilateral Response to Global Climate Change

The Kyoto Protocol signifies a significant step forward in the multilateral response to global climate change by creating specific and legally binding emission reduction commitments for industrialized countries. ${ }^{2}$ According to Jonathan Lash, President of the World Resources Institute:

It's a historic agreement. If countries who sign the treaty put in place the requisite policies and actions, the world will be set on a new course, one which is less dependent on fossil fuels, less polluting and less a threat to human health. ${ }^{3}$

The flexible mechanisms of Kyoto Protocol (International Emissions Trading, Clean Development Mechanism, and Joint Implementation), which allow for trading of certified emission reductions, have brought forth both national and international $\mathrm{CO} 2$ markets (the creation of a carbon market) and ensured the emergence of a price for GHG emissions. ${ }^{4}$ Consequent to the Protocol, governments have already put and are continuing to put in place legislation and policies to meet their commitments. More and more businesses are making the investment decisions needed for a climate-friendly future. ${ }^{5}$

\section{FAILURES OF THE KYOTO PROTOCOL}

5.1 Refusal of United States to Ratify the Protocol and Absence of Binding Targets for Developing Nations The Kyoto Protocol has failed to reduce worldwide greenhouse gas emissions because of, among other things, the United States' refusal to ratify the Protocol. The US has stated as its principal objections to the Kyoto Protocol its potential damage to the US economy and absence of binding targets for developing nations, that is, 'meaningful participation' from the developing world. ${ }^{6}$ Many countries have increased rather than decrease their greenhouse gas emissions since the introduction of the Kyoto Protocol. For example, it is alleged that both India and China's greenhouse gas emissions have increased dramatically. Devoid of binding targets for developing nations, they will only increase their emissions, and it will be harder to reduce them in the future. ${ }^{7}$ China, for example, is now the world's third-largest greenhouse gas emitter after the US and the $\mathrm{EU}^{8}$, and it is believed that China alone will become the world's leading emitter of carbon dioxide in a few years. ${ }^{9}$ Clinton repeated his position on the developing countries, to leave no doubt regarding the American stance at Kyoto:

Both industrialized and developing countries must participate in meeting the challenge of

climate change. The industrialized countries must lead, but binding obligations unless key developing nations meaningfully participate in this effort. ${ }^{10}$

The United States of America further openly declared its refusal to adhere to the Kyoto Protocol through President Bush who expressed the United States of America's position in a letter to US senators in 2001, referring

\footnotetext{
${ }^{1}$ A Guide to Kyoto: Climate Change and What it means to Canadians (International Institute for Sustainable Development (IISD) 1998). (Hereinafter, A Guide to Kyoto).

${ }^{2}$ See Trade and Climate Change, supra note 67.

${ }^{3}$ A Guide to Kyoto, supra note 82 .

${ }^{4}$ Susanne Dröge, The Paris Agreement 2015: Turning Point for the International Climate Regime, Stiftung Wissenschaft und Politik (SWP) Research Paper, German Institute for International and Security Affairs, February 2016 Berlin; See Organisation for Economic Co-operation and Development (OECD), Climate and Carbon: Aligning Prices and Policies, OECD Environment Policy Paper 1 (Paris, 2013).

${ }^{5}$ UNFCCC (2011), supra note 15, pp. 2-3.

${ }^{6}$ Chavez, supra note 77, pp. 6-7; See Daniel Bodansky, U.S. Climate Policy after Kyoto: Elements for Success, Policy Brief, 15 April, 2002, 2002 Carnegie Endowment for International Peace; See Curtis A. Bradley, Unratified Treaties, 'Domestic Politics, and the U.S. Constitution' (2007) 48(2) Harvard International Law Journal, $307-$ $336: 309$.

${ }^{7}$ Chavez, supra note 81 , pp. 6-7.

${ }^{8}$ Page, supra note 25.

${ }^{9}$ Sallie Baliunas, The Kyoto Protocol and Global Warming. The Lavoisier Group Inc, May 2002, p. 3. <https:// www.lavoisier.com.au/articles/greenhouse-science/climate-change/Baliunas.pdf $>$ accessed 10 April 2019.

${ }^{10}$ Anderson, supra note 14, p. 12.
} 
back to the 1997 Byrd-Hagel Senate resolution that the United States should not sign an agreement which contains new greenhouse gas commitments except developing countries as well face such commitments in the same commitment period. President Bush wrote: ${ }^{1}$

As you know, I oppose the Kyoto Protocol because it exempts 80 percent of the world, including major population identifying such as China and India, from compliance, and would cause serious harm to the US economy. The Senate's vote, 95-0, shows that there is a clear consensus that the Kyoto Protocol is an unfair and ineffective means of addressing global climate change concerns."

The subsequent petition disseminated by the Oregon Institute of Science and Medicine has been signed by over 17,000 US scientists, as well as more than 2,000 physicists, geophysicists, climatologists, meteorologists, oceanographers, and environmental scientists and above 4,000 specialists in chemistry, biochemistry, biology, and other life sciences. In fact, according to the Global Warming Petition Project, the petition has been signed by over 31,000 American scientists.

We urge the United States Government to reject the global warming agreement that was written in Kyoto, Japan, in December 1997, and any other similar proposals. The proposed limits on greenhouse gases would harm the environment, hinder the advance of science and technology, and damage the health and welfare of mankind. There is no convincing scientific evidence that human release of carbon dioxide, methane, or other greenhouse gasses is causing or will, in the foreseeable future, cause catastrophic heating of the Earth's atmosphere and disruption of the Earth's climate. Moreover, there is substantial scientific evidence that increases in atmospheric carbon dioxide produce many beneficial effects upon the natural plant and animal environments of the Earth. ${ }^{3}$

More than half of the energy in the US is produced by thermal power plants using coal, generating a large number of emissions of carbon dioxide. According to data from the Oak Ridge National Laboratory, in 2003, the US was responsible for $21.6 \%$ of total carbon dioxide emissions and $28.7 \%$ of carbon dioxide emissions of the twenty largest emitters. If we took the twenty largest emitters in 2003, they are responsible for $75.4 \%$ of total emissions. ${ }^{4}$ It was estimated furthermore, that the US emitted 36.1 percent of the world's greenhouse gases (GHGs) in 1990.

In July 1997, five months ahead of the Kyoto meeting, the US Senate unanimously passed the Byrd-Hagel resolution, which served notice to President Clinton that, any effort to submit the Protocol for ratification as written would result in political defeat. As it bears the sole power to ratify treaties under the Constitution, the Senate preempted the President's course of action on the Protocol, ${ }^{5}$ declaring as follows:

The United States should not be a signatory to any protocol which would (A) mandate new commitments to limit or reduce greenhouse gas emissions for the Annex I Parties unless the Protocol also mandates new specific scheduled commitment for Developing Country Parties within the same compliance period, or (B) result in serious harm to the economy of the United States. ${ }^{6}$

\footnotetext{
${ }^{1}$ Frank Jotzo, Developing Countries and the Future of the Kyoto Protocol. Australian National University Economics and Environment Network Working Paper EEN0406. 15 October 2004 (Economics and Environment Network) p. 4.

${ }^{2}$ Frank Jotzo, ibid; Diniz, supra note 9, p. 34; See Bush, G. W., Text of a letter from the President to Senators Hagel, Helms, Craig, and Roberts (Washington, DC: White House Press Release, 13 March 2001); See Greg Kahn, 'The Fate of the Kyoto Protocol under the Bush Administration' (2003) 21 Berkeley J. Int'l L., 548.

${ }^{3}$ The Kyoto Protocol and Greenhouse Gas Emissions. November 1999. Paper prepared by the Chamber of Commerce and Industry of WA, p. 26. <https://www.aph.gov.au/...Business/.../House_of_Representatives_Com mittees?url...?ky...> accessed 7 May 2019 (Hereinafter, The Kyoto Protocol and Greenhouse Gas Emissions); See Global Warming Petition Project. <http://www.oism.org/pproject/> accessed 5 September 2019.

${ }^{4}$ Diniz, supra note 9 .

${ }^{5}$ Richard W. Thackeray, Jr., 'Struggling for Air: The Kyoto Protocol, Citizens' Suits under the Clean Air Act, and the United States' Options for addressing Global Climate Change' (2004) 14(3) Ind. Int'l \& Comp. L. Rev., 855903:872; Byrd-Hagel Resolution, S. Res. 98, 105th Cong., 143 CONG REC S8113-05 (1997) (enacted); See Nadra Hashim and Free Riders, 'Side Payments, and International Environmental Agreements: Is Kyoto Failing Because Montreal Succeeded' (2009) Winter/Spring The Whitehead Journal of Diplomacy and International Relations, 91109:101.

${ }^{6}$ Jon Hovi, Detlef F. Sprinz and Guri Bang, 'Why the United States did not become a party to the Kyoto Protocol: German, Norwegian, and US Perspectives' (2012) 18(1) European Journal of International Relations, 129150:130; See Joanna Depledge, 'Against the Grain: The United States and the Global Climate Change Regime' (2005) 17(1) Global Change, Peace \& Security, 11-27:16; Jon Hovi, Detlef F Sprinz, and Guri Bang, 'Why the
} 
Because the US is a significant emitter, contributing $35 \%$ of global equivalent $\mathrm{CO} 2$ emissions, its refusal to ratify the Protocol is a significant setback to achieving global greenhouse emission reduction ${ }^{1}$ and casts a shadow over the treaty's future regardless of percentages. ${ }^{2}$ Several regions of the world have experienced a decline in carbon emissions. Still, the expansion of fossil fuel-based industrial development to new areas has yielded an overall increase in global carbon emissions through the 1990s. The United States' carbon emissions rose from 2.86 billion tons in 1960 to 4.80 billion in 1988. Over the same period, China's carbon emissions leaped from 0.79 billion tons to 2.24 billion tons. While the United States' emissions more than doubled between 1950 and 1988 , its percentage of global carbon emissions dropped from forty to twenty-two percent. ${ }^{3}$ Hence, the war against global warming will not be won unless the entire global community is involved. ${ }^{4}$

\subsection{The National Focus of the Kyoto Protocol which Leads to Carbon Leakage (Carbon Switching)}

The primary purpose of the Kyoto Protocol's flexibility mechanisms is to achieve greenhouse gas emission reductions where it is cheapest to do so. Many have expressed concerns about the ability of flexibility mechanisms to support equity and sustainability values. It is argued that the central climate policy as presently formulated, allows for the transfer of burdens of action from wealthier societies who have mainly created the problem to less prosperous nations who are a comparatively weaker political and economic power, which leaves them vulnerable to cooperation. ${ }^{5}$

Carbon leakage is the increase in greenhouse gas emissions in one country as a result of a decrease in another. It is the transfer of emissions from developed countries with stringent climate change policy to developing nations with less strict regulations, resulting in redistribution rather than a reduction in climate-changing emissions. Concerns have been raised that the market mechanisms of the Kyoto Protocol could facilitate carbon leakage. There is an apprehension that the costs imposed by climate change regulations like emission trading could position businesses in countries such as the US at a competitive disadvantage causing energy-intensive industries to run away from the US for countries such as China that lack related restrictions. These mechanisms, it is believed, cannot be effectual except the major emitters like China are involved. ${ }^{6}$

Kyoto's method of dealing with the problem of Third World emissions, namely, basically allowing industrial countries to "trade" emission reductions in the developing nations and shun them domestically, has proved catastrophic. In this regard, Newsweek's Emily Flynn Vencat concluded that the present emissions-trading systems have shown to be little more than a shell game, permitting polluters in the developed world to transfer the burden of making cuts onto factories in the developing countries. The relocation of carbon-intensive industries from participating to non-participating countries is one possible mechanism for such an unintended consequence of the Kyoto Agreement. ${ }^{7}$

Thus, a vital flaw of the Kyoto Protocol is that it seeks to tackle a global problem in terms of national boundaries. In applying such a method, it ignores the reality that the quantity of greenhouse gases emitted or absorbed within a given nation is not a good measure of that country's real impact on worldwide emissions, and will swiftly become less so if emissions-intensive production becomes harder in some countries than others. ${ }^{8} \mathrm{~A}$ government which introduces measures to reduce emissions from within its borders may not affect global emissions if its citizens or previous customers as alternative, buy similar products supplied from countries not subject to emissions targets. This process is known as "carbon switching." Indeed, a country-by-country approach could have some unwelcome and (probably) unintended consequences.

United States did not become a party to the Kyoto Protocol: German, Norwegian and US perspectives' (2010) 18(1) European Journal of International Relations, 1-22:2; See Senate Resolution 98. Congressional Record, Report No. 105-5412, June 1997.

${ }^{1}$ See Shaheen Rafi Khan, supra note 9.

${ }^{2}$ Thackeray, supra note 96, p. 871.

${ }^{3}$ Ibid, p. 859.

${ }^{4}$ Nikhil R. Ullal, A Successor for the Kyoto Protocol - Challenges and Options Associated with a Post-Kyoto Protocol Regime, p. 28. <https:/heinonline.org/hol-cgi-bin/get_pdf.cgi?handle=hein.journals/nzjel17...7> accessed 9 April 2019.

${ }^{5}$ UNFCCC (2003), supra note 15; Muhovic-Dorsner, supra note 50; See Kamala Muhovic-Dorsner, K., 'Evaluating Climate Change Policy in the European Union: An Ecological Justice Approach' (2005) 25(3) The Bulletin of Science, Technology and Society, 238-246; See Schreuder, Y., The Corporate Greenhouse: Climate Change Policy and Greenhouse Gas Emissions (London and New York: Zed Books 2009).

${ }^{6}$ Olawuyi, supra note 48.

${ }^{7}$ Jeffrey A. Frankel, The Impact of a Revised Kyoto Protocol on Developing Countries: For Business and Economy, July 21, 2004. <https://pdfs.semanticscholar.org/9bbd/2e5e54fa5d17c9ee/bacbb.114a864b6cefoe.pdf > accessed 5 March 2019.

${ }^{8}$ The Kyoto Protocol and Greenhouse Gas Emissions, supra note 94. 
The Kyoto Protocol could offer a veneer of respectability for the ongoing process of rich countries transferring dirty production processes to developing nations. Analysis of developing and developed countries' pollution patterns by World Bank points to a shift of polluting activity to more impoverished countries:

Stricter regulation of pollution-intensive production in the OECD countries appears to have led to significant locational displacement, with the consequent acceleration of industrial pollution intensity in developing countries. The poorest economies seem to have the highest growth in toxic intensity. ${ }^{1}$

The Protocol applies currently to a limited group of countries, those that are industrialized or in the transition to a market economy. Consequently, with factors of production costing more as a result of the higher price of emission rights (and of tax and regulatory restraints), several companies that come under the Protocol will shift their production to countries that are not part of it. Worldwide greenhouse gas emissions will not be reduced: instead, the sources will be transferred to countries that do not come under Kyoto. ${ }^{2}$ Even overlooking the problems of entry into force, one must acknowledge that the Kyoto Protocol was certainly not anticipated to provide the definitive set of solutions to achieve the ultimate objective of the UNFCCC, which is, stabilizing atmospheric concentrations of greenhouse gases. New steps will be needed. At best, Kyoto is only the beginning. ${ }^{3}$

\subsection{Developing Countries' Argument on Equity and Universality of the Right to Economic Development}

The issue of developing country participation is central to Annex I countries' concerns over the future of the Protocol. Non-Annex I countries account for a substantial and increasing proportion of global greenhouse gas (GHG) emissions; no reductions regime can be successful without meaningful developing country reductions. At the same time, the principle of "mutual or common but differentiated responsibilities" by which Annex I countries agreed to begin reductions first is central to the political equation that has allowed negotiations to proceed. Progress towards an effective emissions reductions regime will, therefore, require unprecedented international consensus. ${ }^{4}$

However, the subject is very controversial. First, on the one hand, developing countries point out that they should not have to sacrifice their economic development, or otherwise pay the economical price, for a problem that the industrialized countries created. The view of developing countries is quite correct: Most of the earlier emissions of greenhouse gases that are accumulated presently in the atmosphere came from the industrialized nations. In contrast, rich countries draw attention to the fact that it is not feasible to deal with the problem except developing countries fully participates in the system. The view of the industrialized countries as well is correct: most of the expected increase in emissions in the coming decades comes from China, India, and other developing countries. Second, the developing countries are of the view that they should not be obligated to take any step that entails economic sacrifice until the industrialized countries have done so. There are two grounds for this: one, the industrialized countries created the problem, and two, they are more prosperous and can more readily afford to make some sacrifice. ${ }^{5}$

Many argue that the industrialized countries should take the first steps to combat climate change since they are responsible for the bulk of human-made current greenhouse gas concentrations. ${ }^{6}$ Developing countries did not commit to precise reductions, mainly for two grounds. Their main concerns are economic growth and poverty reduction; and secondly, industrialized countries consume far more energy, and therefore generate far additional greenhouse gases. For instance, Canadians make use of 30 times more energy than nationals of India on a per capita basis. Also, it has been estimated that ever since the 19th century Industrial Revolution, Europe, and North America have produced 85 percent of the human-induced carbon dioxide in the atmosphere at the moment. The developing nations see Kyoto as an examination of whether the world's economic superpowers are serious about

${ }^{1}$ Ibid, p. 8; See Lucas, Robert E.B. et al., Economic Development, Environmental Regulation, and the International Migration of Toxic Industrial Pollution: 1960-88, Policy, Research Working Papers; No. 1062 (World Development Report, Washington DC, World Bank 1992).

${ }^{2}$ The Economic Costs and Ineffectiveness of the Kyoto Protocol. Economic Note, September 2006, Institute Economic Molinari, p. 2 <www.institutmolinari.org/IMG/pdf/note20066.pdf> accessed 9 February 2019 (Hereinafter, The Economic Costs and Ineffectiveness of the Kyoto Protocol).

${ }^{3}$ Cédric Philibert, 'Lessons from the Kyoto Protocol: Implications for the Future' (2004) 5(1) International Review for Environmental Strategies, $\mathrm{xx}-\mathrm{xxx}$.

${ }^{4}$ Márcio Santilli et al, 'Tropical Deforestation and the Kyoto Protocol: An Editorial Essay' in Paulo Moutinho and Stephan Schwartzman (eds), Tropical Deforestation and Climate Change (Amazon Institute for Environmental Research: Springer 2005) pp. 50, 272.

${ }^{5}$ Frankel, supra note 104.

${ }^{6}$ Sheila M. Olmstead and Robert N. Stavins, A Meaningful Second Commitment Period for the Kyoto Protocol, p. 1. <https://scholar.harvard.edu/files/stavins/.../olmstead_stavins_for_economist_voice.pdf $>$ accessed 11 May 2019. 
climate change. ${ }^{1}$

The developing countries regard the Kyoto Protocol as a manifestation of the historical responsibility of the industrialized countries for global greenhouse gas emissions. ${ }^{2}$ The majority of the emissions increase more than the past 200 years happened as a result of the economic expansion of developed countries. Understandably, developing countries contend that the current greenhouse gas crisis is the obligation of the developed countries. Additionally, they claim to have the same right to pursue economic growth as those countries which industrialized earlier, even if this means making the same addition to greenhouse gas emissions in the process. Again, this is a reasonable argument. On a collective basis, nearly half of the global greenhouse gas emissions already emanate from developing countries, and the majority of projections indicate that this share will increase over the next few decades. Still assuming no change in the allocation of economic activity due to the implementation of the Kyoto Protocol, reductions in emissions in the richer countries alone will not be adequate to halt the growth of global greenhouse gas emissions. A further realistic model, which supposes that some emissions-producing activity would switch from countries with emission controls to those without could see a negligible slowing in global emissions growth (and could conceivably show that the Kyoto Protocol will generate an increase in emission levels). ${ }^{3}$

Developing countries' governments remind us that the industrialized countries supported and based (and continue to support and base) their economic growth on activities with massive greenhouse gas emissions. People in developing countries also desire to profit from these activities with their vast growth prospective. In this background, there is a slight possibility that developing countries will agree to a "broadened" Kyoto protocol and apply it efficiently if it stops them from benefitting from the development prospects that rich countries profited from in the past and continues to benefit from today. ${ }^{4}$ The developing country bloc argued that the Berlin Mandatethe terms of reference of the Kyoto negotiations established at COP-1 in 1995-clearly excluded them from new commitments in this Protocol, and they continued to oppose non-Annex I countries emissions limitation commitments. $^{5}$

While developing countries didn't create the problem, it argued that they would have to be part of the solution, since several countries like China, India, South Korea, Brazil etc-currently have large, rapidly expanding industrial sectors. It is believed that sometime shortly, developing countries will produce more than 50 percent of the world's greenhouse gas emissions. ${ }^{6}$ Therefore, any international strategy to reduce greenhouse gas emissions without the participation of developing countries will not successfully work. And except developing countries can be accommodated in an emissions reduction strategy in an equitable manner that does not exclude them from attaining economic development, they will decline to participate. ${ }^{7}$

\subsection{It is Alleged that Kyoto Protocol Deters Development and Results to Reduction in Purchasing Power and Quality of Life}

The Kyoto Protocol depends on governments applying tax and regulatory instruments that oblige companies to emit lesser quantities of greenhouse gases, the aim being to increase production costs and lower earnings for activities that generate greenhouse gases. The Kyoto Protocol created emission rights "market" that would further reduce earnings. For the reason that the purchase of emission rights entails an extra cost, cost-effective and gainful production will be lower. These rights tend to become increasingly expensive as time goes on since the aim of the Protocol is to reduce greenhouse gas emissions. Accordingly, we can expect the number of emission rights to remain low to raise the cost of using technologies considered as "dirty." 8

Companies will find these rights progressively challenging to purchase. With the restrictions imposed by the Kyoto stipulations, several companies will be incapable of bearing losses from investments with no profits and costs new spending on "clean" technologies requires. Additional to this are the costs ensuing from the reality that resources diverted to meet up the Protocol's numerous hundred billion dollars yearly will be unavailable for companies to invest, or individuals to spend, on other more beneficial projects. Therefore, the Kyoto protocol will hurt our standard of living. By increasing production costs, it will penalize activities that emit greenhouse gases. Businesses suspected of contributing directly or indirectly to global warming are everywhere- in heating and

\footnotetext{
${ }^{1}$ A Guide to Kyoto, supra note 78, pp. 4-5; See The impacts of climate change are felt most by the Southern countries. $<$ https://e-bangla.blogspot.com/2011/11/impacts-of-climate-change-are-felt-most.html $>$ accessed 5 September 2019.

${ }^{2}$ Dröge, supra note 85, p. 24.

${ }^{3}$ The Kyoto Protocol and Greenhouse Gas Emissions, supra note 94, p. 10.

${ }^{4}$ The Economic Costs and Ineffectiveness of the Kyoto Protocol, supra note 107, pp. 3-4.

${ }^{5}$ Fletcher, supra 40, pp. 3-4.

${ }^{6} \mathrm{~A}$ Guide to Kyoto, supra note 82.

${ }^{7}$ The Kyoto Protocol and Greenhouse Gas Emissions, supra note 94.

${ }^{8}$ The Economic Costs and Ineffectiveness of the Kyoto Protocol, supra note 107, p. 2.
} 
cooling, energy production, the manufacture of different raw materials (plastic, steel, etc.), product processing, powering of our several electrical appliances (lighting, computers, household appliances, etc.). The scale of these activities is apparent in our weekly shopping trips. It aids us to appreciate that Kyoto, by escalating the prices of all goods involving the production of greenhouse gases, unavoidably decreases our purchasing power and quality of life. ${ }^{1}$

Years later, with the EU cap-and-trade scheme in crisis, high energy costs are accelerating Europe's economic decline. The economic impacts in EU countries that adopted climate regulations, including Germany, Italy, Spain, and the UK, have been disastrous. Grave fears are now being raised over the economic viability of their manufacturing sectors as well as budget and energy poverty concerns. Recent testimony from Stephen D. Eule, Vice President of the Institute for 21st Century Energy, of the US Chamber of Commerce, at 18 November 2015, EPW Committee hearing, entitled, "Examining the International Climate Negotiations," shed light on this issue:

That continent's expensive energy prices, mostly policy-driven, are ruining its competitiveness and turning energy-intensive industries into endangered species. More and more, we are seeing European companies fleeing sky-high energy costs and shifting production to the United States and other countries. ${ }^{2}$

Further, a 21 December 2015, Wall Street Journal article, entitled, "Obama the Unilateral Climate Warrior," expanded on these impacts:

For Europe, the Kyoto Protocol has forced the EU States to adopt unilateral, and disastrously costly, decarbonization policies. With their manufacturers rapidly losing ground to international competition, governments are increasingly concerned about the threat high energy prices pose to Europe's industrial base. ${ }^{3}$

Australia has also learned from the economic pains of climate action. In July 2014, Australia's parliament repealed a 2012 carbon tax. In remarks on Australia's repeal, Senator Inhofe explained in an op-ed entitled, "Obama's climate goals have already failed," published in The Hill on September 2014: Government regulations limiting greenhouse gas emissions are de facto brakes on any economy. Those who dispute or doubt this need look to Australia for a compelling case study. That country's carbon tax imposed a significant drag on its economy, and once Australia's political leaders summoned the will to repeal the tax in July, job creation improved. ${ }^{4}$

This testimony, among other findings, was documented in a May 2008 EPW Committee Staff Report under then-Ranking Member Inhofe, which declared:

The Kyoto Protocol, an international cap-and-trade system to control and reduce greenhouse gas emissions, has become a worldwide failure. Aside from constraining growth in all developed countries and allowing unrestricted development in countries such as China and India, Kyoto would not help to stop global warming. ${ }^{5}$

For instance, Agricultural production in the United States is energy-intensive, with fertilizers, pesticides, and fuel representing a significant share of variable costs of production. Even in the land-intensive Northern provinces grain production methods examined here, these energy-related costs characteristically involve about half of the short-range variable costs of production. Agricultural producers are worried that the effect of cost increases associated with compliance with the Kyoto Protocol could adversely impact their competitiveness, mainly because their competitors in the developing countries are not subject to emissions reductions under the Protocol. ${ }^{6}$

\section{CONCLUSION}

Climate change is the central concern of our time and dealing with climate change will entail an extraordinary effort from all sectors of society. ${ }^{7}$ As was emphasized at the Climate Action Summit, the climate emergency is a

${ }^{1}$ Ibid.

${ }^{2}$ Lessons from Kyoto: Paris Agreement will fail National Economies and the Climate. Majority Staff White Paper - United States Senate Committee on Environment and Public Works, 114th Congress, April 21, 2016, p. 15 (Hereinafter, Lessons from Kyoto); See Examining the International Climate Negotiations: Hearing before the Subcomm. on Clean Air \& Nuclear Safety of the S. Comm. on Env't \& Pub. Works, 114th Cong., Nov. 18, 2015. ${ }^{3}$ Lessons from Kyoto, ibid note 121, pp. 15-16; See Benny Peiser, 'Obama the Unilateral Climate Warrior' Wall St. J. (USA December 21 2015).

${ }^{4}$ Lessons From Kyoto, ibid, p. 16; See Sen. James M. Inhofe, 'Obama’s Climate Goals have already Failed' The Hill (USA September 22 2014).

${ }_{5}^{5}$ Lessons from Kyoto, ibid, p. 15; See The Economics of America's Climate Security Act Of 2007: S. 2191, “Lieberman-Warner Climate Bill,” U.S. S. Comm. on Env’t \& Pub. Works, Minority Staff White Paper, May 2008.

${ }^{6} J o h n$ M. Antle, et al, 'The Kyoto Protocol: Economic Effects of Energy Prices on Northern Plains Dryland Grain Production’ (1999) 28(1) Agricultural and Resource Economics Review, 96.

${ }^{7}$ United Nations UN Climate Change Action Summit, 23 September 2019. <https://www.un.org >climatechang e> 
race we are losing-but it is a race we can triumph if we amend our habits now ${ }^{1}$ Without urgent and determined action, it will destroy delicate ecosystems, hinder development endeavours, raise threats to public health, obstruct poverty mitigation programs, and force large-scale migration from water or food-insufficient areas. The socialeconomic and environmental costs of inaction will far exceed the cost of taking immediate steps to address climate change. ${ }^{2}$

In line with the above view, the World Resources Institute in Washington has studied the economics of a delaying strategy and concludes as follows:

1. Policies and tax incentives are required now to encourage research, mass production, and marketing of less carbon-intensive energy alternatives.

2. The longer we wait, the higher the accumulation of fossil-fuel dependent vehicles, appliances, and equipment, and the additional troublesome and expensive future greenhouse gas reductions will be.

3. Without early action, the potential gains from greenhouse gas reduction policies, such as enhanced air value, improved savings from energy effectiveness, and improved energy security, will be lost.

4. A climate protection policy based on a clear strategy of delay-doing little or nothing now and later is not credible. Without precise market and policy signals in the near term, emissions will continue to rise, whereas capital investments and technological developments will go on much as before, making it difficult, not easier, to execute policies and to frighten more significant, not less, disruption in the future. ${ }^{3}$

Therefore, it is now imperative that we must step up our collective climate action to save the world from its verge of climate catastrophe. Urgent action is needed in other to realize a significant reduction in global greenhouse gas emissions. The Kyoto Protocol Mechanisms, that is, International Emissions Trading, Clean Development Mechanism, and Joint Implementation, also known as the Kyoto Carbon Market, ought to have been reviewed, expanded, and made more inclusive. In other words, both developed and developing countries need to have been involved in global greenhouse gas emission reduction for the Kyoto Protocol to achieve its aim. The involvement of the United States-a significant emitter of greenhouse gases cannot be overemphasized. Thus, the United States ought to have ratified the Kyoto Protocol and, like other industrialized countries, come under specific emission reduction targets.

Emerging significant emitters of greenhouse gases from developing countries such as China and India should consider a departure from the use of technologies that contributes to climate change to technologies that reduce climate change through the stabilization of greenhouse gas emissions. The contributions of developing countries to greenhouse gas emissions reduction should however be based on the principle of common but differentiated responsibilities. More so, the problem of carbon switching, which was identified as one of the significant challenges of the Kyoto Protocol, should be addressed in future climate change policies, for example, the Paris Climate Agreement.

Finally, while national resolutions and policies can impact the climate change problem, the global community must change its thinking, outlook, and approach before any significant global greenhouse gas emissions reduction can be achieved. Thus, the only means to reduce global greenhouse gas emissions and, at the same time, realizing anticipated economic development is to cause a complete change in the technologies that dominate the manufacturing sector, energy sector, transportation sector, and agricultural sector. We must speedily dispose of the outdated techniques that have added so richly to the present climate change problems and substitute them with contemporary techniques created and intended with global environmental sustainability in view.

accessed 27 September 2019.

${ }^{1}$ U.N. Head Warns Leaders, supra note 2.

${ }^{2}$ Facilitating an International Agreement on Climate Change: Adaptation to Climate Change. Global Leadership for Climate Action (GLCA), June 2009, p. 10. <https://www.preventionweb.net/go/10267> accessed 8 May 2019.

${ }^{3}$ A Guide to Kyoto, supra note 82, p. 9. 